\title{
Lactobacillus senmaizukei sp. nov., isolated from Japanese pickle
}

\author{
Kazumi Hiraga, ${ }^{1}$ Yoshie Ueno, ${ }^{2}$ Sirapan Sukontasing, ${ }^{3}$ \\ Somboon Tanasupawat ${ }^{3}$ and Kohei Oda ${ }^{1}$
}

Correspondence

Kohei Oda

bika@kit.ac.jp

\author{
${ }^{1}$ Department of Applied Biology, Graduate School of Science and Technology, Kyoto Institute of \\ Technology, Goshokaido-cho, Matsugasaki, Sakyo-ku, Kyoto 606-8585, Japan \\ ${ }^{2}$ Kyoto Prefectural Technology Center for Small and Medium Enterprise, 134 Chudoji, \\ Minamimachi, Shimogyo-ku, Kyoto 600-8813, Japan \\ ${ }^{3}$ Department of Microbiology, Faculty of Pharmaceutical Sciences, Chulalongkorn University, \\ Bangkok 10330, Thailand
}

Japan, like many other countries, has a long tradition of producing pickles. Pickles can be used as good screening sources for the isolation of valuable micro-organisms, e.g. lactic acid bacteria. Recently, a bacterium, strain $\mathrm{L} 13^{\mathrm{T}}$, was isolated from senmaizuke, one of the traditional fermented pickles made from Japanese radish in Kyoto, Japan (Ueno et al., 2007). In this study, strain $\mathrm{L} 13^{\mathrm{T}}$ was assessed using phenotypic and chemotaxonomic characteristics, $16 \mathrm{~S}$ rRNA and RNA polymerase alpha subunit $(r p o A)$ gene sequence analyses and DNA-DNA relatedness studies. The results showed that strain $\mathrm{L} 13^{\mathrm{T}}$ represents a novel species of the genus Lactobacillus.

\footnotetext{
The GenBank/EMBL/DDBJ accession numbers for the $16 \mathrm{~S}$ rRNA and rpoA gene sequences of strain $L_{13}{ }^{\top}$ are AB297927 and AB359074, respectively. The accession number for the $r p o A$ gene sequence of Lactobacillus parabrevis ATCC $53295^{\top}$ is AB359076.

Phylogenetic trees based on 16S rRNA gene sequences derived by the neighbour-joining (Supplementary Fig. S1), maximum-likelihood (Supplementary Fig. S2) and maximum-parsimony (Supplementary Fig. S3) methods showing the position of Lactobacillus senmaizukei $\mathrm{L}_{13^{\top}}$ among selected lactobacilli are available with the online version of this paper.
}

One hundred colonies were isolated from senmaizuke after cultivation on GYP agar plates (Ueno et al., 1997) at $30{ }^{\circ} \mathrm{C}$ for 5 days. Colonies were cultivated anaerobically in GYP liquid medium containing $5 \%$ sodium glutamate at $30{ }^{\circ} \mathrm{C}$ for $48 \mathrm{~h}$. The culture supernatant of each isolate was analysed for production of $\gamma$-aminobutyric acid by TLC (Ueno et al., 2007); strain $\mathrm{L} 13^{\mathrm{T}}$ was obtained as a high-level producer of $\gamma$-aminobutyric acid. Cell morphology, Gram staining, colony appearance, spore formation and catalase activity were examined on GYP agar after incubation for $48 \mathrm{~h}$. Sugar fermentation patterns were determined using the API $50 \mathrm{CH}$ and API $50 \mathrm{CHL}$ kits (bioMérieux) over a period of $72 \mathrm{~h}$ cultivation at $30{ }^{\circ} \mathrm{C}$. An F-kit DL-lactic acid (Roche Diagnostics) was used to determine production of D- and L-lactic acids from glucose. The effects of various temperatures on growth were determined by using GYP broth at 15,30 and $45{ }^{\circ} \mathrm{C}$. Bacterial growth was monitored by measurement of $\mathrm{OD}_{660}$. Tolerance of $\mathrm{NaCl}$ was examined by adding $1,2,3,4,5,6,7,8,9$ and $10 \%$ $(\mathrm{w} / \mathrm{v}) \mathrm{NaCl}$ to GYP broth. Production of ammonia from arginine was determined according to the method of AboElnaga \& Kandler (1965). The cell wall composition was determined according to Schleifer \& Kandler (1972). 
DNA was isolated by using the lytic enzyme labiase according to the method of Niwa et al. (2005) with some modifications. Genomic DNA was extracted from $0.36 \mathrm{~g}$ wet weight cells as follows. After addition of $0.36 \mathrm{ml} 0.1 \mathrm{M}$ acetate buffer $(\mathrm{pH} 4.0)$ and $0.36 \mathrm{ml} 4 \mathrm{mg}$ labiase $\mathrm{ml}^{-1}$ to the cells, the cell suspension was incubated for $10 \mathrm{~min}$ at $55{ }^{\circ} \mathrm{C}$. After this incubation, $0.39 \mathrm{ml} 20 \%$ SDS was added and the suspension was mixed gently and incubated for $5 \mathrm{~min}$ at $55{ }^{\circ} \mathrm{C}$. After addition of $2 \mu \mathrm{l} 5 \mathrm{mg}$ RNase solution $\mathrm{ml}^{-1}$, the suspension was incubated at $37^{\circ} \mathrm{C}$ for $1 \mathrm{~h}$. Subsequent chloroform/isoamyl alcohol extraction, precipitation and spooling of DNA on a glass rod were performed as described by Marmur (1961). The isolated genomic DNA was used for amplification of the 16S rRNA gene by PCR using primers 27f (5'-AGAGTTTGATCCTGGCTCAG- $\left.3^{\prime}\right)$ and $1492 \mathrm{r}\left(5^{\prime}\right.$-GGCTACCTTGTTACGACTT$3^{\prime}$ ) (Weisburg et al., 1991). The rpoA gene was amplified as described by Naser et al. (2005). The rpoA gene of Lactobacillus parabrevis ATCC $53295^{\mathrm{T}}$ was also amplified and analysed since it was not available in the database. Phylogenetic trees were constructed by the neighbourjoining method (Saitou \& Nei, 1987) using the NJPLOT program (Perrière \& Gouy, 1996) and by the maximumlikelihood (Felsenstein, 1989) and maximum-parsimony methods using MEGA version 3.1 (Kumar et al., 2004). Confidence values of branches of the phylogenetic tree were determined using bootstrap analysis (Felsenstein, 1985) based on 1000 resamplings. DNA-DNA hybridization was carried out as described by Ezaki et al. (1989) and the $\mathrm{G}+\mathrm{C}$ content of the DNA was determined according to Mesbah et al. (1989). Metabolites from glucose were analysed by HPLC. A Develosil RPAQUEOUS-AR-5 column (Nomura Chemical) was used for organic acid detection (detection, $210 \mathrm{~nm}$; mobile phase, acetonitrile; column oven, $35{ }^{\circ} \mathrm{C}$ ) and a Develosil C30-UG-5 column (Nomura Chemical) was used for ethanol detection (detection, refractive index detector; mobile phase, miliQ water; column oven, $40{ }^{\circ} \mathrm{C}$ ).

Strain $\mathrm{L} 13^{\mathrm{T}}$ was characterized phenotypically and genotypically (Table 1). It was a heterofermentative, facultatively anaerobic, Gram-positive, non-spore-forming, non-motile, catalase-negative, rod-shaped bacterium. Based on $16 \mathrm{~S}$ rRNA gene sequence similarity (Fig. 1), strain L13 belonged to the genus Lactobacillus and it was closely related to Lactobacillus hammesii CIP $108387^{\mathrm{T}}$ (98.9\%), L. parabrevis ATCC $53295^{\mathrm{T}}$ (98.5\%) and Lactobacillus brevis LMG $6906^{\mathrm{T}}(97.6 \%)$. Additional trees constructed by the neighbour-joining, maximum-likelihood and maximumparsimony methods are available as Supplementary Figs S1, S2 and S3, respectively, in IJSEM Online. In addition, the rpoA gene sequence of strain $\mathrm{L} 13^{\mathrm{T}}$ showed similarities of 92.2 and $92.0 \%$ to L. hammesii CIP $108387^{\mathrm{T}}$ and $L$. parabrevis ATCC $53295^{\mathrm{T}}$, respectively, as shown in Fig. 2. Thus, $r p o A$ gene analysis also showed that strain $\mathrm{L} 13^{\mathrm{T}}$ was closely related to these strains. L. parabrevis ATCC $53295^{\mathrm{T}}$ was isolated from wheat and originally deposited with the ATCC as L. brevis (Spiller, 1987); it has recently been reclassified as $L$. parabrevis ATCC $53295^{\mathrm{T}}$ (Vancanneyt et al., 2006). DNA-DNA relatedness values of strain $\mathrm{L}^{1} 3^{\mathrm{T}}$ to L. parabrevis ATCC $53295^{\mathrm{T}}$ and L. hammesii CIP $108387^{\mathrm{T}}$ were 8.3 and $6.3 \%$, respectively. These values are below the

Table 1. Differential characteristics of strain $L 13^{\top}$ and closely related Lactobacillus species

Strains: 1 , L13 ${ }^{\mathrm{T}} ; 2$, L. parabrevis ATCC $53295^{\mathrm{T}}$ (data from Vancanneyt et al., 2006); 3, L. hammesii CIP $108387^{\mathrm{T}}$

(Valcheva et al., 2005). +, Positive; -, negative; w, weakly positive; ND, not determined.

\begin{tabular}{|lccc|}
\hline Characteristic & $\mathbf{1}$ & $\mathbf{2}$ & $\mathbf{3}$ \\
\hline $\mathrm{NH}_{3}$ from arginine & - & + & - \\
Acid production from: & & & + \\
$\quad$ Aesculin & + & + & + \\
L-Arabinose & - & + & $\mathrm{ND}$ \\
D-Arabitol & - & - & + \\
Cellobiose & - & + & + \\
D-Fructose & $\mathrm{W}$ & + & $\mathrm{ND}$ \\
D-Gluconate & $\mathrm{W}$ & - & $\mathrm{ND}$ \\
2-Keto-D-gluconate & $\mathrm{W}$ & + & + \\
N-Acetylglucosamine & $\mathrm{W}$ & + & + \\
D-Glucose & $\mathrm{W}$ & + & + \\
Maltose & - & - & + \\
Mannitol & - & - & + \\
Mannose & - & + & $\mathrm{ND}$ \\
D-Ribose & + & - & + \\
Trehalose & - & + & + \\
Methyl $\beta$-xyloside & - & 49 & 52.6 \\
DNA G+C content (mol\%) & 46 & & \\
\end{tabular}




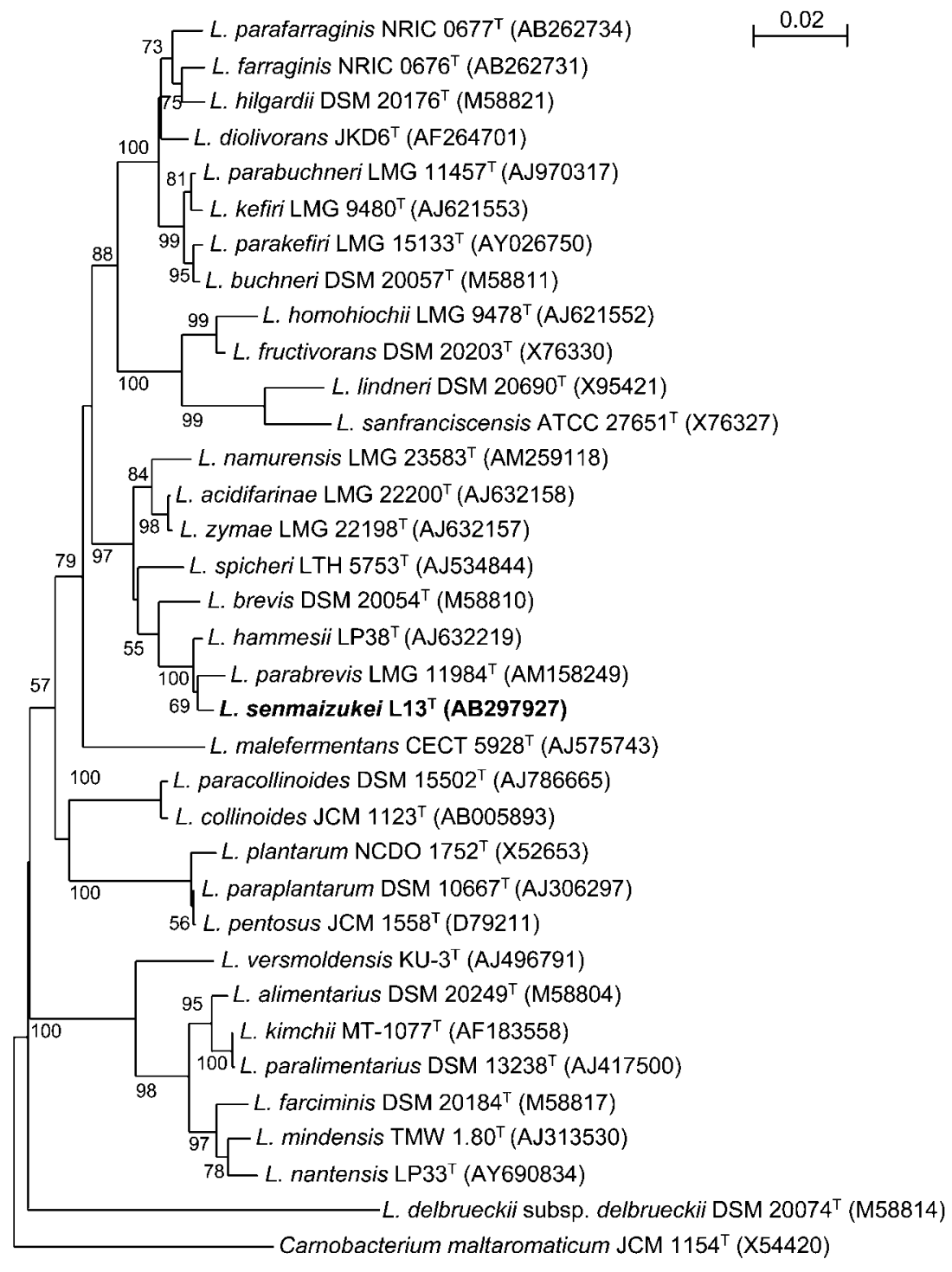

Fig. 1. Phylogenetic tree derived from $16 \mathrm{~S}$ rRNA gene sequence analysis showing the position of Lactobacillus senmaizukei $\mathrm{L}_{13}{ }^{\top}$ among selected lactobacilli. The tree was generated by the neighbour-joining method. Bootstrap percentages above $55 \%$, based on 1000 replications, are given at nodes. Bar, 0.02 substitutions per nucleotide position. threshold of $70 \%$ suggested for species delineation (Wayne et al., 1987; Stackebrandt \& Goebel, 1994), thus indicating that strain $\mathrm{L} 13^{\mathrm{T}}$ represents a separate genomic species. The DNA G $+\mathrm{C}$ content of strain $\mathrm{L} 13^{\mathrm{T}}$ was $46 \mathrm{~mol} \%$, which is within the range (32-55 mol\%) reported for other species of the genus Lactobacillus (Kandler \& Weiss, 1986). The cell wall composition was lysine and aspartic acid, indicating peptidoglycan type A4 $\alpha$ L-Lys-D-Asp. Strain $\mathrm{L}^{1} 3^{\mathrm{T}}$ could not produce acid from $\mathrm{L}$-arabinose, methyl $\beta$-xyloside or maltose. It could grow slowly and heterofermentatively in glucose-containing medium (GYP) at $30{ }^{\circ} \mathrm{C}$ and a small amount of DL-lactate was detected in the medium. Based on its biochemical properties, sugar fermentation patterns, DNA G + C content and DNA-DNA hybridization experiments, strain $\mathrm{L} 13^{\mathrm{T}}$ clearly differed from $L$. parabrevis ATCC $53295^{\mathrm{T}}$ (Vancanneyt et al., 2006) and L. hammesii CIP $108387^{\mathrm{T}}$ (Valcheva et al., 2005). Thus, strain $\mathrm{L} 13^{\mathrm{T}}$ represents a novel species of the genus Lactobacillus, for which the name Lactobacillus senmaizukei is proposed.

\section{Description of Lactobacillus senmaizukei sp. nov.}

Lactobacillus senmaizukei (sen.mai.zu'ke.i. N.L. n. senmaizukeum senmaizuke, a traditional fermented pickle; N.L. gen. n. senmaizukei of senmaizuke, referring to the isolation of the type strain from a traditional fermented pickle produced in Kyoto, Japan).

Cells are Gram-positive, catalase-negative, non-motile, non-spore-forming rods $(0.5-0.8 \times 1.0-5.0 \mu \mathrm{m})$. Colonies on GYP agar are circular, low-convex with entire margins and non-pigmented (1.0-2.0 $\mathrm{mm}$ in diameter after 2 days of growth). Can grow in up to $8.0 \% \mathrm{NaCl}$ and at $15{ }^{\circ} \mathrm{C}$, but not at $45{ }^{\circ} \mathrm{C}$. The specific growth rate in $5.0 \% \mathrm{NaCl}$ is $50 \%(100 \%$ growth without $\mathrm{NaCl})$. Facultatively anaerobic. Produces DL-lactic acid heterofermentatively from glucose. Acetic acid and ethanol are also produced as other metabolites (HPLC analysis). Acid is produced from aesculin, D-fructose, D-galactose, D-gluconate, 2-keto-Dgluconate, $N$-acetylglucosamine, D-ribose and D-xylose, but 


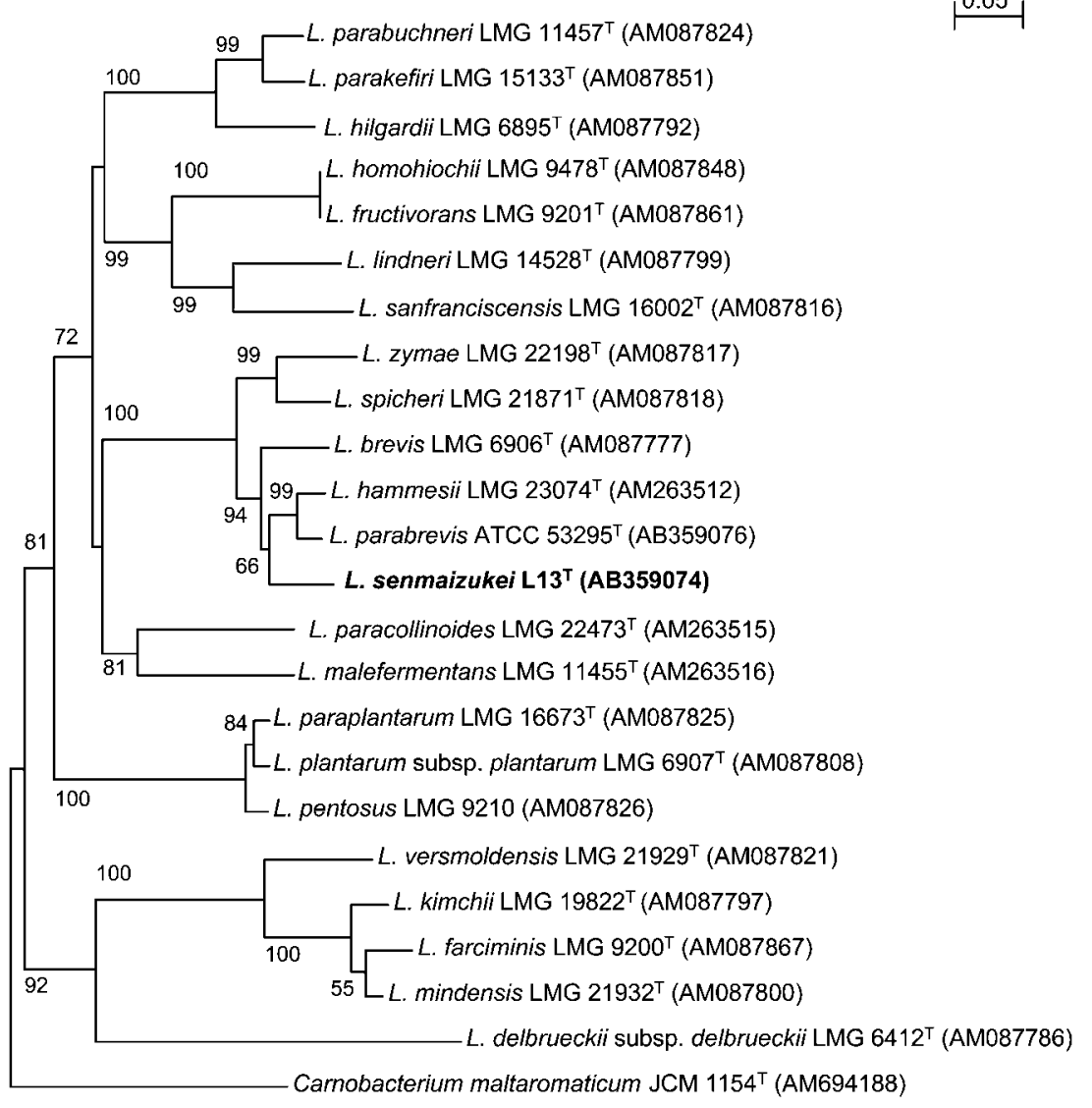

Fig. 2. Phylogenetic tree based on $r p o A$ gene sequences showing the relationship between Lactobacillus senmaizukei $\mathrm{L}_{13}{ }^{\top}$ and selected lactobacilli. The branching pattern was generated by the neighbour-joining method. Bootstrap percentages above $55 \%$, based on 1000 replications, are shown at nodes. Bar, 0.05 substitutions per nucleotide positions. not from adonitol, D-amygdalin, arabinose, arabitol, arbutin, dulcitol, erythritol, cellobiose, gentiobiose, 5-keto-D-gluconate, methyl $\alpha$-D-glucoside, glycogen, glycerol, inositol, inulin, lactose, D-lyxose, maltose, Dmannitol, D-mannose, methyl $\alpha$-D-mannoside, melezitose, melibiose, raffinose, L-rhamnose, salicin, sorbitol, L-sorbose, starch, sucrose, D-tagatose, trehalose, turanose, xylitol, L-xylose or methyl $\beta$-xyloside. Ammonia is not produced from arginine. Peptidoglycan structure is of the A4 $\alpha$ L-LysD-Asp type.

The type strain, $\mathrm{L} 13^{\mathrm{T}}\left(=\mathrm{NBRC} 103853^{\mathrm{T}}=\right.$ TISTR $\left.1847^{\mathrm{T}}\right)$, was isolated from senmaizuke, one of the traditional pickles from Kyoto, Japan. The DNA G $+\mathrm{C}$ content of the type strain is $46 \mathrm{~mol} \%$.

\section{References}

Abo-Elnaga, I. G. \& Kandler, O. (1965). Zur Taxonomie der Gattung Lactobacillus Beijerinck. I. Das Subgenus Streptobacterium Orla-Jensen. Zentralbl Bakteriol Parasitenkd Infektionskr Hyg 119, 1-36 (in German).

Ezaki, T., Hashimoto, Y. \& Yabuuchi, E. (1989). Fluorometric deoxyribonucleic acid-deoxyribonucleic acid hybridization in microdilution wells as an alternative to membrane filter hybridization in which radioisotopes are used to determine genetic relatedness among bacterial strains. Int J Syst Bacteriol 39, 224-229.

Felsenstein, J. (1985). Confidence limits on phylogenies: an approach using the bootstrap. Evolution 39, 783-791.
Felsenstein, J. (1989). PHYLIP - phylogeny inference package (version 3.2). Cladistics 5, 164-166.

Kandler, O. \& Weiss, N. (1986). Genus Lactobacillus Beijerinck 1901, $212^{\mathrm{AL}}$. In Bergey's Manual of Systematic Bacteriology, vol. 2, pp. 12091234. Edited by P. H. A. Sneath, N. S. Mair, M. E. Sharpe \& J. G. Holt. Baltimore: Williams \& Wilkins.

Kumar, S., Tamura, K. \& Nei, M. (2004). MEGA3: Integrated software for molecular evolutionary genetics analysis and sequence alignment. Brief Bioinform 5, 150-163.

Marmur, J. (1961). A procedure for the isolation of deoxyribonucleic acid from microorganisms. J Mol Biol 3, 208-218.

Mesbah, M., Premachandran, U. \& Whitman, W. B. (1989). Precise measurement of the $\mathrm{G}+\mathrm{C}$ content of deoxyribonucleic acid by highperformance liquid chromatography. Int J Syst Bacteriol 39, 159-167.

Naser, S. M., Thompson, F. L., Hoste, B., Gevers, D., Dawyndt, P., Vancanneyt, M. \& Swings, J. (2005). Application of multilocus sequence analysis (MLSA) for rapid identification of Enterococcus species based on rpoA and pheS genes. Microbiology 151, 2141-2150.

Niwa, T., Kawamura, Y., Katagiri, Y. \& Ezaki, T. (2005). Lytic enzyme, labiase for a broad range of Gram-positive bacteria and its application to analyze functional DNA/RNA. J Microbiol Methods 61, 251-260.

Perrière, G. \& Gouy, M. (1996). WWW-query: an on-line retrieval system for biological sequence banks. Biochimie 78, 364-369.

Saitou, N. \& Nei, M. (1987). The neighbor-joining method: a new method for reconstructing phylogenetic trees. Mol Biol Evol 4, 406-425.

Schleifer, K. H. \& Kandler, O. (1972). Peptidoglycan types of bacterial cell walls and their taxonomic implications. Bacteriol Rev 36, 407-477. 
Spiller, M. A. (1987). Admixture of a Lactobacillus brevis and a Saccharomyces dairensis for preparing leavening barm. US Patent 4,666,719. 19 May 1987, US Patent Office.

Stackebrandt, E. \& Goebel, B. M. (1994). Taxonomic note: a place for DNA-DNA reassociation and $16 \mathrm{~S}$ rRNA sequence analysis in the present species definition in bacteriology. Int J Syst Bacteriol 44, 846-849.

Ueno, Y., Hayakawa, K., Takahashi, S. \& Oda, K. (1997). Purification and characterization of glutamate decarboxylase from Lactobacillus brevis IFO 12005. Biosci Biotechnol Biochem 61, 1168-1171.

Ueno, Y., Hiraga, K., Mori, Y. \& Oda, K. (2007). Isolation and utilization of a lactic acid bacterium, producing a high level of $\gamma$ aminobutyric acid (GABA). Seibutsu-kogaku Kaishi 85, 109-114 (in Japanese).

Valcheva, R., Korakli, M., Onno, B., Prévost, H., Ivanova, I., Ehrmann, M. A., Dousset, X., Gänzle, M. G. \& Vogel, R. F. (2005). Lactobacillus hammesii sp. nov., isolated from French sourdough. Int J Syst Evol Microbiol 55, 763-767.

Vancanneyt, M., Naser, S. M., Engelbeen, K., De Wachter, M., Van der Meulen, R., Cleenwerk, I., Hoste, B., De Vuyst, L. \& Swings, J. (2006). Reclassification of Lactobacillus brevis strains LMG 11494 and LMG 11984 as Lactobacillus parabrevis sp. nov. Int J Syst Evol Microbiol 56, 1553-1557.

Wayne, L. G., Brenner, D. J., Colwell, R. R., Grimont, P. A. D., Kandler, O., Krichevsky, M. I., Moore, L. H., Moore, W. E. C., Murray, R. G. E. \& other authors (1987). International Committee on Systematic Bacteriology. Report of the ad hoc committee on the reconciliation of approaches to bacterial systematics. Int J Syst Bacteriol 37, 463-464.

Weisburg, W. G., Barns, S. M., Pelletier, D. A. \& Lane, D. J. (1991). $16 \mathrm{~S}$ ribosomal DNA amplification for phylogenetic study. J Bacteriol 173, 697-703. 